\title{
Educational Values In Caricature Art In Suara Merdeka Newspaper 2017 Edition
}

\author{
Jimin Budiyono ${ }^{1}$,Tjetjep Rohidi $\mathrm{R}^{1}$, Totok Sumaryanto $\mathrm{F}^{1}$, Dharsono Sony \\ Kartika $^{1}$ \\ \{jimboodee@gmail.com, tcetceprohidi@gmail.com, totoksumaryanto@gmail.com\} \\ Universitas Negeri Semarang ${ }^{1}$
}

\begin{abstract}
The purpose of this study is to explain and analyze caricature art in Suara Merdeka newspaper 2017 edition which has relevance to the values of education. The steps of this research use a qualitative method with a hermeneutic approach, the location of the research is the Editor of Suara Merdeka Semarang Central Java Province. Data obtained through observation, interviews and documentation (archives). Data analysis uses analysis interaction with the sociology approach. Educational theory is used to analyze the values of caricature art education in the 2017 edition of Suara Merdeka newspaper. The results of the study show that Suara Merdeka Editors contribute to the education of the community, entertain the reading community, establish communication with the reading community, build a reading culture community.
\end{abstract}

Keywords: Caricature, Education, entertainment, reading culture.

\section{Introduction}

An artist in creating art has a specific purpose and purpose, which is presented to the public in the hope that the work can be appreciated by the public as connoisseurs of art. The works of art created by artists are not merely embodiments that appear in plain sight, but in those works contain a human problem that is manifested in the language of art, so that art can be used as a teaching and learning method that is in line with AndiSukriSyamsuri's research [1] Said the effectiveness of the use of caricature media in learning to write paragraphs and arguments.

An artist's concern for a phenomenon that occurs in the midst of society, is a form of contribution and a sense of moral responsibility as a social creature. An artist's contribution to the nation and state is manifested in the form of works of art, proof of manifestation and participation in educating human mentality to become virtuous and noble human beings, through the message conveyed.

Caricature artwork is created by a caricaturist because of a concern for human behavior, some of which have diverged from the life of the nation and state, thereby displacing moral values that are incompatible with traditional customs and culture, so that a caricaturist contributes to education through work his creation in the form of educational criticism. In line with the final observations of the results of UgurBasarmak and AhmetMahioglu [2] "students' success in learning environments with caricature animations is significantly higher than in learning without animation animation. 
The purpose of this study is to explain and analyze caricature artworks in the 2017 edition of SuaraMerdeka newspaper that have relevance to the value of education in the community, so that the kariktur artworks can entertain the public because of the presentation of funny pictures, enough to contain humorous content, in accordance with Benjamin's research Picado[3], which focuses the morphology of humor in caricatures, distinguishes visual forms that discuss the relationship between the style of caricature stylist and laughter poetry.

The benefits of caricature art in SuaraMerdeka 2017 Edition newspaper that have relevance to the value of education for life and for the advancement of science are to realize every human behavior both individually and in general in order to make human beings themselves into noble human beings that are useful for homeland and Nation, such as the research of Kirsten Walsh and Adrian Currie [4] that discusses pedagogic situations that require clean lies, teaching philosophy makes what must be eliminated, emphasized and distorted.

\section{Methodology}

Research conducted using qualitative methods that are process-oriented research, and suitable for solving human behavior problems, prioritizing validity (degrees of trust) rather than reliability, not prioritizing large numbers of subjects or objects and emphasizing thick descriptions. The research uses a hermeutic approach meaning that every event or work has value from the interpretations of the actors or the makers. A work or event that is an interpretation of something facing a reader or observer that is captured by interpretation as well. The research includes observations, interviews, documentation and validation, using data analysis interactions and analytical interpretations with an artistic philosophy approach that discusses values in art activities or certain qualities of an art work.

The main data sources are 2 caricature art pictures in the 2017 edition of SuaraMerdeka newspaper which have relevance to educational values. data collection instruments using digital cameras, cellphones, recording devices and notebooks using a ballpoint. An informant is someone who knows and in accordance with his field that is a caricaturist, observer, journalist and newspaper reader community who know about caricature arts and art educators. Data collection techniques using interactive analysis schemes include, data collection, data presentation, data reduction and conclusion drawing. The data analysis technique uses an analytical interpretation scheme that includes works of art, educational studies and the value of works of art. Data validity is done using triangulation (expert judgment).

\section{Result and Discussion}

\subsection{Result}

The caricature of the 2017 edition of SuaraMerdeka newspaper that has relevance to the educational value of which is entitled: "PCC: (ParacetamolCafeinCaricoprodol) is a form of drug type pill which is prohibited by the government for consumption, because it can damage the soul or mentality of humans. The picture is a form of criticism that educates drug dealers and drug users to be vigilant and return to the right path, because consuming drugs will damage lives and threaten human lives. "Judicial Mafia" is a form of criticism that educates law enforcement officials so that the law does not become a game, is not easily bribed, not 
sharp downward blunt upward, so the public wants law enforcement officials to really uphold justice and truth.

\subsection{Discussion}

The emergence of caricature art ideas in SuaraMerdeka 2017 newspaper is the meaning of an important event that occurs in society related to morality or human behavior, such as rampant cases of corruption, drugs, excessive use of social media and community behavior that contains other immoral elements, so realization of the caricature drawings above the newspaper mass media to be presented to the public, in order to know the specific meaning of the event to be used as learning. So with the caricature content in the SuaraMerdeka newspaper, it is an embodiment of education for the community through the criticism conveyed. In line with the research of X.Anton Castro Fernandez [5] who made himself a new devotee starting from journalism as a communicative and social tool, the awareness of a satire gamarian and caricature gave a version in line with the period of magazines and newspapers. The caricaturist ideas originated from journalists who covered a variety of phenomena in society, then to be published through newspaper media.

Educational Values in Caricature Art in Suara Merdeka Newspaper 2017 Edition. The manifestation of karukatur art works in Suara Merdeka newspaper media is an artistically arranged form, so that the art form in its realization is arranged using artistic principles and elements. In its manifestation, attention to the phenomenon of life in the midst of society from an event related to human behavior that touches the mind. A form of soul calling for a caricaturist, which is in accordance with Mica Pollock's research [6] namely "How a teacher at the time of professional development for diversity, hears the task as a call to perform super humanitarian tasks. Like the sample pictures below, the educational values are as follows:

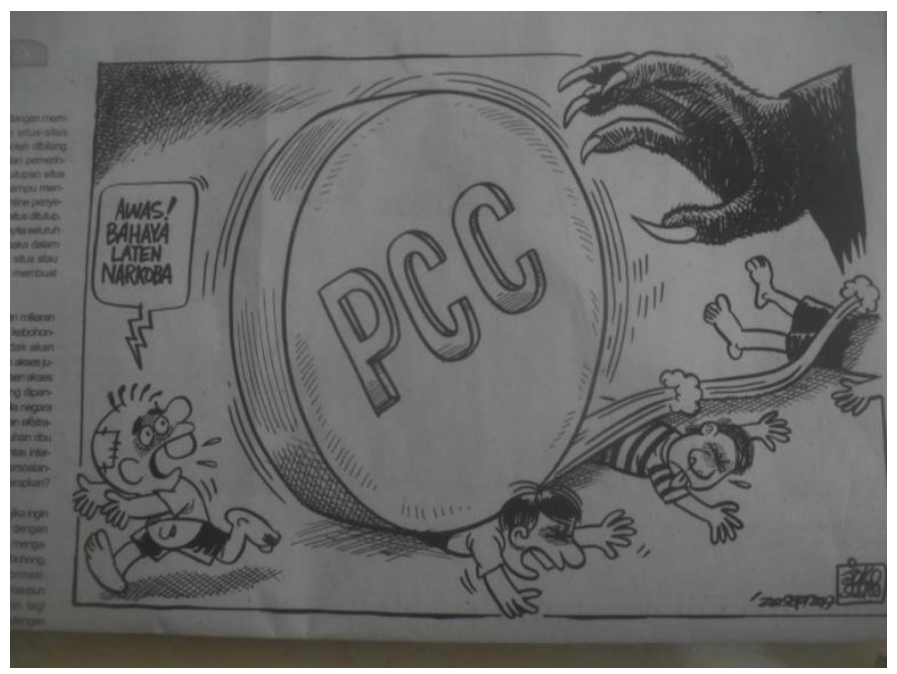

Fig. 1. Suara Merdeka, PCC, edition : 20 September 2017.

The shape of the picture is a depiction of a pill in the form of a circle that reads PCC (Paracetamol Caffein Carisoprodol) which seems to crush several people in front of it, there is a feared person who is threatened and there is an inscription on his head "Be aware of the 
dangers of latent drugs", above the corner right there is a hand with sharp nails and hairy creepy like a monster.The shape of the picture is a depiction of a pill in the form of a circle that reads PCC (Paracetamol Caffein Carisoprodol) which seems to crush several people in front of it, there is a feared person who is threatened and there is an inscription on his head "Be aware of the dangers of latent drugs", above the corner right there is a hand with sharp nails and hairy creepy like a monster.

The caricature art provides a description of an event that has occurred regarding the circulation of PCC pills in the community, which includes new types of drugs that have claimed many lives. The pill is consumed by the younger generation of drug addicts, which are produced in Purwokerto, Semarang and Sukoharjo Solo (Suara Merdeka 4 December 2017 page: 1). The newspaper explained that the National Narcotics Agency (BNN) and Central Java National Narcotics Agency (BNNP) also raided PCC raw material storage facilities in Sukoharjo. This disclosure reinforces the fact that Central Java is a large scale warehouse and PCC factory. So the government expressly forbids the circulation or production of these illicit goods. The educational value in the picture is to criticize a PCC pill trafficking event that is mentally damaging and life threatening to a person or drug addicts. The point is that the government invites the public to act or behave properly and not consume drugs.

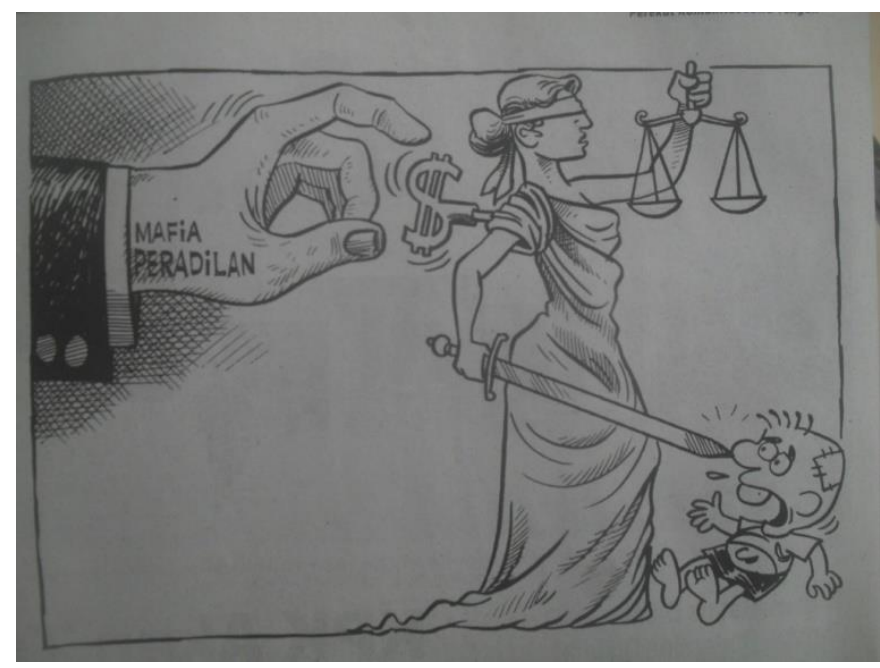

Fig. 2. Suara Merdeka, Mafia Peradilan, edition : 11 October 2017.

The analysis of caricature art is an upholder of justice who does not want to see the truth. Examples of incidents of violence perpetrated by the state apparatus against journalists and civil society originated from the act of caring about Mount Slamet which was not supposed to end with chaos. As reported in the "Editorial" Wednesday 11 October 2017 page 4 which contained "Violence against journalists and demonstration participants in front of the Banyumas Regent's Office rejecting the establishment of a Geothermal Power Plant at the foot of Mount Slamet to invite mutual concern. Journalists, DPR members, academics, and student alliances have condemned the repressive culture practiced by the police. The culture of violence of the state apparatus against citizens should not be tolerated. the perpetrators of these crimes include those from the police and government officials appropriately in the legal process " 
The value of education in the caricature is in the form of kririk towards the justice enforcement apparatus, so that it invites state officials to act according to the applicable rules, not to abuse their authority, so as to create peace, order and security as well as comfort and not arbitrary.

\section{Conclusion}

Presentation of caricature art in SuaraMerdeka newspaper edition 20 September 2017 and 11 October 2017 edition as a form of image that is entertaining and educates the public in the form of criticism of a phenomenon in society related to drugs and law enforcement. The incident was made an example of human behavior that is not good, because it will damage the harmony of civilized and cultured in society, so it is not appropriate to imitate. The event was a form of moral education contribution carried out by a SuaraMerdekacharacterist. SuaraMerdeka also contributes to the culture of reading towards the community, through its actual news on the media of newspapers or newspapers distributed to the public. 


\section{Reference}

[1] Syamsuri, A.S.: The Effectiveness of Caricatre Media in Learning Writing of Argumentation Paragraph. Makasar, Indonesia, Muh Arief Langue and Education Faculty University Muhammadiyah (2016).

[2] Basarmak, U. \& Mahioglu, A.: The Effect of online Learning Environment Based on Carikature Animation Used in Science and Technology Course on the Success and Attitude of the Student for Humor, Turkish, online Journal Education Technology (2016).

[3] Picado, B.: Beyond the Fixity of Drawing:Aspectuality and Narrative Vertualities of Depsction in Caricature, Niteroi, Rio de Janeiro, Journal of Graphic Novel and Comics, Departemen of media studies, Fluminence Federal University (2016).

[4] Walsh, K. \& Currie, A.: Caricatures, Myths, and White Lies, Metaphilosophy LLC and John Wiley \& Sons Ltd.(2015)

[5] Fernandez, X. \& Castro, A.: Journalism Caricatre and Satircal Drawing in Early Picass(18911895): The Awakening of Plablo Ruiz's Critical Consciousness. Universidad de Vigo, Callede la Maestransa 2, Lecturer in Art History in the Pontevedra. (2016)

[6] Pollock, M.; Bocala, C.; Deckman, S.L. \& Staub, S.D.: Caricature and Hyperbole in Preservice Teacher Provessional Development for Diversity, Article Urban Education the Author (2016). 